\title{
Influence of Brazilian vegetable oils on mechanical resistence of hair fiber
}

\author{
Influência de óleos vegetais brasileiros na resistência mecânica da fibra capilar
}

\author{
Maria Valéria Velascoํ, Tatiana Santana Balogh¹, Erica Junko Waki Kagiyama1, Michelli Ferrera Dario, \\ Robson Miranda Gama1, Valcinir Bedin ${ }^{2}$ and André Rolim Baby ${ }^{1}$ \\ ${ }^{1}$ School of Pharmaceutical Sciences, University of São Paulo, Departement of Pharmacy, 580, Prof. Lineu Prestes Avenue, \\ BI - 13/15, São Paulo - SP, Brazil \\ ${ }^{2}$ Hair and Skin Research and Treatment Institute, 69, São Domingos, São Paulo - SP, Brazil \\ Email: michelli.dario@usp.br
}

\begin{abstract}
Associating the global trend of incorporating active compounds and plants in cosmetic formulations and the vast Brazilian biodiversity, the present work aimed to study the incorporation of Brazilian vegetable oils in hair conditioner formulations, evaluating the mechanical resistance of hair fibers. The following oils were incorporated into base formulations at $5.0 \%(\mathrm{w} / \mathrm{w})$ : babassu, buriti, andiroba and pequi. The formulations were applied to samples of Caucasian hair, followed by several washing steps, then the evaluation of mechanical strength. It was found that there was no statistically significant difference in mechanical resistance between samples treated with oils and the control between the first and seventh wash cycles. This fact can be explained by the possible low penetration of oils into the cortex, a region responsible for the mechanical properties of the hair fiber, since the grease composition disfavors its diffusion. The common effects of vegetable oils on the cuticle, such as filling in cracks or cavities, lubrication, and increased protein hydrophobicity cannot be excluded. The oils tested in this work were not able to raise or protect hair tresses. However, additional studies are required in order to establish the effects of oil treatments, particularly in damaged hair.
\end{abstract}

Keywords: hair, emulsion, vegetable oils, mechanical properties

\section{Resumo}

Associando a tendência global de incorporar ingredientes ativos derivados de plantas em formulações cosméticas e da enorme biodiversidade brasileira, o presente trabalho teve como objetivo estudar a incorporação de óleos vegetais brasileiros em condicionadores capilares, avaliando-se seu efeito na resistência mecânica da fibra do cabelo. Os seguintes óleos foram incorporados a uma formulação base a 5,0 \% (p/p): babaçu, buriti, andiroba e pequi. As formulações foram aplicadas a mechas de cabelo Caucasiano, seguido de um procedimento de lavagem, sendo resistência mecânica posteriormente avaliada. Verificou-se que não havia nenhuma diferença estatisticamente significativa na resistência mecânica entre as mechas tratadas com os diferentes óleos e o controle entre o primeiro e o sétimo ciclos de lavagem. Este fato pode ser explicado pela baixa penetração dos óleos no córtex, uma região responsável pelas propriedades mecânicas da fibra capilar, uma vez que sua composição desfavorece a difusão. Os efeitos comuns de óleos vegetais na cutícula, como preencher fendas ou cavidades, lubrificação e aumentar a hidrofobicidade não pode ser excluída. Portanto, os óleos testados neste trabalho não foram capazes de aumentar ou proteger as mechas de cabelo nas condições experimentais utilizadas. No entanto, mais estudos são necessários para determinar seus efeitos, principalmente em cabelos danificados.

Palavras-chave: cabelo, emulsão, óleos vegetais, propriedades mecânicas 


\section{Introduction}

The use of extracts, fixed oils, resins, honey, dyes and essential oils with cosmetic purpose originated in antiquity. Currently, we observe the intensive use of vegetable bases and natural active ingredients in the cosmetics industry. In Brazil, the expansion of the natural or natural-based products industry is mainly aimed at the foreign market. According to the Brazilian Association of Toiletries, Perfumes \& Cosmetics (ABIHPEC), products made from fruits, seeds and other natural ingredients lead Brazilian exports. Between 1996 to 2013, many toiletries, perfumery and cosmetics were formulated with active principles from plants, and achieved a cumulative growth of $775 \%$ (1).

Brazil presents a fertile ground for the development of research in this area, due to its biodiversity field. It is the country with the greatest plant genetic diversity in the world, with 55,000 cataloged species of an estimated 350,000-550,000. The magnitude of Brazilian biodiversity is not accurately known due to its complexity, but it is estimated that there are over two million different species of plants, animals and micro-organisms (2). In 2012, the composition of the Brazilian cosmetics industry showed that $19.4 \%$ of total revenues originated from products intended for hair care. The human hair fiber is a keratinized filament which grows from hair follicles that extend from the dermis to the epidermis, with glandular and muscular components. Properties such as friction, stiffness, bending, static load and diameter are some features that can differentiate hair fibers and variations may be observed over a single fiber (3-4).

With the advent of electron microscopy in the 1950s, the structure and morphology of hair could be described. It belongs to a group of proteins called $\alpha$-keratins, proteins arranged in helical polypeptide chains which are formed by an insoluble cystine group, with a high content of disulfide bonds (SS). These bridges are responsible for the formation of a three-dimensional network with high crosslink density, which gives hair greater resistance to attack by products used in chemical treatments, such as dying and relaxing. The hair fiber, composed of spindle cells, contains water, lipids and pigments (melanin) in addition to $\alpha$-keratin. It has three or four layers: cuticles (about $10 \%$ of the fiber), cortex (about $88 \%$ ), cell membrane complex (about $2 \%$ ) and possibly medulla (5-7).

Several products with active ingredients for hair care include plant ingredients in their composition. Hair conditioners, cosmetic emulsions containing essentially cationic surfactant in combination with long chain fatty alcohols and other lipid components, are one such product. Cationic surfactants reduce the accumulated static electricity of hair fibers, and lipid components are deposited on the fibers. The function of conditioners is to improve hair styling, shine, softness, volume, smoothness, handling, color, and shape, among others (8).

\section{Introdução}

O uso de extratos, óleos fixos, resinas, mel, tinturas e óleos essenciais com finalidade estética nasceu na Antiguidade. Atualmente, percebemos o uso intensivo de bases vegetais e ingredientes ativos naturais na indústria de cosméticos. No Brasil, a expansão da indústria natural, ou com base em produtos naturais, é voltada principalmente para o mercado externo. De acordo com a Associação Brasileira de Higiene Pessoal, Perfumaria e Cosméticos (ABIHPEC), os produtos feitos a partir de frutas, sementes e outros ingredientes naturais lideram as exportações brasileiras. Entre 1996 e 2013, muitos dos produtos de higiene pessoal, perfumaria e cosméticos foram formulados com princípios ativos de plantas, e obtiveram um crescimento acumulado de $775 \%$ (1).

O Brasil apresenta um terreno fértil para o desenvolvimento de pesquisas nesta área, devido a sua elevada biodiversidade. É o país com a maior diversidade genética vegetal do mundo, com apenas 55 mil espécies catalogadas de um total estimado de 350.000 - 550.000. A magnitude da biodiversidade brasileira não é conhecida com precisão, devido a sua complexidade, mas estima-se que existem mais de dois milhões de espécies diferentes de plantas, animais e microrganismos (2).

A composição do volume de negócios da indústria de cosméticos do Brasil, em 2012, mostrou que 19,4 \% do total da receita é proveniente de produtos destinados ao cuidado do cabelo. A fibra do cabelo humano é um filamento queratinizado que cresce a partir de folículos pilosos que se estendem desde a derme para a epiderme, com componentes glandulares e musculares. Aspectos como o atrito, rigidez, carga estática e diâmetro são algumas características que podem diferenciar as fibras do cabelo e variações podem ser observadas ao longo de uma única fibra (3-4). Com o advento de microscopia electrónica na década de 1950, a estrutura e morfologia de cabelo puderam ser descritos. Ela pertence a um grupo de proteínas chamado $\alpha$-queratinas, proteínas dispostas em cadeias polipeptídicas helicoidais, que são formadas por um grupo cistina insolúvel, com elevado teor de ligações dissulfeto (SS). Estas pontes são responsáveis pela formação de uma rede tridimensional, com elevada densidade de reticulação que dá ao cabelo maior resistência aos produtos químicos, como tinturas e alisantes. A fibra do cabelo é constituída por células fusiformes e contém, além de $\alpha$-queratina, água, lípidos e pigmentos (melanina). Ela tem três ou quatro camadas: cutículas (cerca de $10 \%$ da fibra), córtex (cerca de $88 \%$ ), complexo de membrana celular (cerca de $2 \%$ e, eventualmente, medula (5-7).

Vários produtos para o cuidado dos cabelos possuem componentes vegetais em sua formulação, tais como os condicionadores. Estas são emulsões cosméticas contendo surfactante essencialmente catiônico em combinação com álcoois graxos de cadeia longa e outros componentes lipídicos. Os surfactantes catiônicos reduzem a electricidade estática acumulada de componentes de fibra capilar, e lípidos são depositados sobre a fibra. 
Associating the global trend of incorporating active ingredients and plant derivatives in cosmetic formulations and Brazilian biodiversity, the present work aimed to study the incorporation of Brazilian vegetable oils in hair conditioner formulations, evaluating the mechanical strength of Caucasian hair fibers by determining the mechanical (breaking) strength.

\section{Material and methods}

\section{Hair care formulations}

Four Brazilian vegetable oils were used in this study: babassu (Orbignya phalerata Mart.), buriti (Mauritia flexuosa L.), andiroba (Carapa guianensis Aubl.) and pequi (Caryocar brasiliense Camb). Four bioactive hair conditioner formulations were prepared by the incorporation of $5.0 \%(\mathrm{w} / \mathrm{w})$ of the oils to the base formulation (Table 1).
A função dos condicionadores é melhorar características como brilho, maciez, volume e forma, entre outros (8). Associando a tendência global de incorporar ingredientes ativos e derivados de plantas da biodiversidade brasileira em formulações cosméticas, o presente trabalho teve como objetivo estudar a incorporação de óleos vegetais brasileiros em formulações de condicionadores de cabelo e avaliar a resistência mecânica de fibras capilares caucasianas.

\section{Material e Métodos}

Formulações de tratamento do cabelo

Quatro óleos vegetais brasileiros foram usados neste estudo: babaçu (Orbignya phalerata Mart.), buriti (Mauritia flexuosa L.), andiroba (Carapa guianensis Aubl) e pequi (Caryocar brasiliense Camb). Quatro formulações de condicionadores capilares bioativos foram preparadas pela incorporação de 5,0\% (p/p) dos óleos na formulação base (Tabela 1. )

Table 1/ Tabela 1. Quantitative composition of base hair care formulation. *INCI: International Nomenclature of Cosmetic Ingredients.

Composição quantitative da formulação capilar base. *INCI: International

Nomenclature of Cosmetic Ingredients.

\begin{tabular}{c|c}
\hline \multicolumn{2}{c}{$\begin{array}{c}\text { Base formulation } \\
\text { Formulação base }\end{array}$} \\
\hline $\begin{array}{c}\text { Components *INCI } \\
\text { Componentes INCI* }\end{array}$ & $\begin{array}{c}\text { Proportion }(\% \mathrm{w} / \mathrm{w}) \\
\text { Proporção }(\% \mathrm{p} / \mathrm{p})\end{array}$ \\
\hline Aminopropyl phenyl trimethicone & 6.0 \\
\hline Cetearyl alcohol & 4.5 \\
\hline $\begin{array}{c}\text { Ethylene Glycol Distearate } \\
\text { Phenoxyethanol, Methylparaben, Ethylparaben, } \\
\text { Propylparaben, Butylparaben, } \\
\text { Isobutylparaben. }\end{array}$ & 1.5 \\
\hline Butilhidroxi Tolueno & 0.5 \\
\hline Cetrimonium Chloride & 0.5 \\
\hline Cera Alba (Beeswax) & 2.0 \\
\hline Fragance & 3.0 \\
\hline Aqua q.s.p. & q.s. \\
\hline
\end{tabular}




\section{Preparation of hair tresses}

Six hair tresses were prepared with virgin Caucasian hair (De Meo Brothers Inc.), $1.0 \mathrm{~cm}$ width and $10.0 \mathrm{~cm}$ long. The tresses were previously washed with $1 \mathrm{ml}$ of a surfactant dispersion and $20 \mathrm{~mL}$ of distilled water (at $\left.(37.0 \pm 1.0){ }^{\circ} \mathrm{C}\right)$, and then dried under controlled temperature and humidity conditions (at $\left.(21.0 \pm 2.0)^{\circ} \mathrm{C}\right)$ and $60 \%$ relative humidity). Approximately $0.6 \mathrm{~g}$ of each formulation developed was applied equally to the tresses. The tresses were in contact with the formulation for 15 minutes, then were rinsed with distilled water (at $(37.0 \pm 1.0){ }^{\circ} \mathrm{C}$ ) and dried under the conditions described previously. A control tress (C) was also washed with the surfactant dispersion, but received no treatment with the hair conditioner. The application of hair care formulations and washing cycles were repeated, reaching a total of seven cycles of treatment. The control tress was only subjected to seven washing cycles.

\section{Mechanical resistance}

Analysis of breaking strength was performed in a texturometer (TAXT2 Analyzer $\AA$ ), operating at speed traction from the clutches of $300 \mathrm{~mm} / \mathrm{min}$, distance of $80 \mathrm{~mm}, 25.0 \mathrm{~kg}$ load and sensitivity of $0.49 \mathrm{~N}$. The tensile strength was calculated by the ratio between the maximum force in rupture (in Newton) and the fiber cross-sectional area. Diameters were measured with a micrometer (Mitutoyo ${ }^{\circledR}$ ), in three positions (root, middle portion and tip), and the mean value was used to calculate the total area of the hair fiber. The tests were conducted with the tresses after the first, fourth and seventh procedure washing cycle.

\section{Statistical analysis}

Statistical analysis was performed using STATISTICA ${ }^{\circledR}$ Release 7.0 software. Data were subjected to analysis of variance homogeneity by the Hartley test, followed by the Kruscall-Wallis test, considering $\mathrm{p}<0.05$.

\section{Results and Discussion}

The mean values of the tensile strength after the three cycles of the application of formulations $n$ washing (first, fourth and seventh) are shown in Table 2.

After the first application of hair care formulation and washing procedure ( $1^{\circ}$ cycle), the value of tensile strength of the control tress did not differ statistically from the other tresses. It was observed that the base with pequi oil formulation had higher mean tensile strength than the others, however, in relation to the control, the average resistance values did not differ statistically.

\section{Preparo das mechas de cabelo}

Seis mechas de cabelo foram preparadas com cabelo virgem Caucasiano (De Meo Brothers Inc.), largura de 1,0 centímetro e $10,0 \mathrm{~cm}$ de comprimento. As mechas foram previamente lavadas com $1 \mathrm{ml}$ de dispersão de agente tensoativo e $20 \mathrm{~mL}$ de água destilada (a (37,0 \pm $1,0)^{\circ} \mathrm{C}$ ). Em seguida, as mechas secaram sob condições controladas de temperatura e umidade $(\mathrm{a}(21,0 \pm 2,0)$ ${ }^{\circ} \mathrm{C}$ ) e $60 \%$ de umidade relativa). Cerca de $0,6 \mathrm{~g}$ de cada formulação desenvolvida foram aplicadas nas mechas, permaneceram em contato durante $15 \mathrm{~min}$, e em seguida foram lavadas com água destilada (a $(37,0 \pm 1,0)$ ${ }^{\circ} \mathrm{C}$ ) e secas nas condições descritas anteriormente. Uma mecha controle (C) também foi lavada com a dispersão do agente tensoativo, mas não recebeu tratamento com o condicionador capilar. Algumas aplicações de condicionador e ciclos de lavagem foram realizados, chegando a um total de sete ciclos de tratamento. A mecha controle foi submetido somente aos sete ciclos de lavagem.

\section{Resistência mecânica}

Análise da tração à ruptura foi realizada em texturômetro modelo TAXT2 Analyzer $^{\circledR}$, operando a velocidade de tração das garras de $300 \mathrm{~mm} / \mathrm{min}$, distância de $80 \mathrm{~mm}$, carga de teste de $25,0 \mathrm{~kg}$ e sensibilidade de 0,49 N. A resistência à tracção foi calculada pela razão entre o força máxima na ruptura (em Newton) e a área em corte transversal da fibra. Os diâmetros foram medidos com micrómetro Mitutoyo ${ }^{\circledR}$, em três posições da fibra (raiz, ponta e meio), e o valor médio foi utilizado para calcular a área total da fibra capilar. Os testes foram realizados com os cabelos após o primeiro, quarto e último ciclo de lavagem.

\section{Análise estatística}

A análise estatística foi realizada no software Statisti$\mathrm{ca}^{\circledR}$ versão 7.0. Os dados foram submetidos à análise de variância pelo teste de homogeneidade Hartley, seguido pelo teste Kruscall-Wallis, considerando-se p $<0,05$.

\section{Resultados e Discussão}

Os valores médios da resistência à tração após três ciclos de lavagem são mostrados na Tabela 2.

Após a primeira aplicação da formulação para o cuidado do cabelo e procedimento de lavagem ( $1^{\circ}$ ciclo), o valor da resistência à tração da mecha controle não diferiu estatisticamente dos demais. Observou-se que a formulação base com óleo de pequi tinha resistência à tração média maior do que os outros, no entanto, em relação ao controle, os valores médios não diferiram estatisticamente. 
Table 2/ Tabela 2. Tensile strength of Caucasian hair tresses after cycles of application of formulations and washing

Tração à ruptura de mechas de cabelo Caucasiano após ciclos de aplicação de formulação e lavagens

\begin{tabular}{|c|c|c|c|}
\hline \multirow{2}{*}{$\begin{array}{l}\text { Treatment } \\
\text { Tratamento }\end{array}$} & \multicolumn{3}{|c|}{$\begin{array}{c}\text { Tensile strength }\left(\mathrm{N} / \mathrm{mm}^{2}\right) \pm \mathrm{SD} \\
\text { Tração à ruptura }\left(\mathrm{N} / \mathrm{mm}^{2}\right) \pm \mathrm{DP}\end{array}$} \\
\hline & $\begin{array}{l}1^{\circ} \text { cycle } \\
1^{\circ} \text { ciclo }\end{array}$ & $\begin{array}{l}4^{\circ} \text { cycle } \\
4^{\circ} \text { ciclo }\end{array}$ & $\begin{array}{l}7^{\circ} \text { cycle } \\
7^{o} \text { ciclo }\end{array}$ \\
\hline $\begin{array}{l}\text { Control } \\
\text { Controle }\end{array}$ & $0.09 \pm 0.13 \mathbf{a b ~ A}$ & $0.07 \pm 0.02 \mathbf{a} \quad \mathbf{A B}$ & $0.05 \pm 0.01 \mathbf{a ~ A C}$ \\
\hline Base & $0.06 \pm 0.01 \mathbf{a} \quad \mathbf{A}$ & $0.08 \pm 0.02 \mathbf{a} \quad \mathbf{B}$ & $0.05 \pm 0.01 \mathbf{a} \quad \mathbf{C}$ \\
\hline $\begin{array}{l}\text { Base + babassu oil } \\
\text { Base }+ \text { óleo de babaçu }\end{array}$ & $0.06 \pm 0.01 \mathbf{a} \quad \mathbf{A}$ & $0.11 \pm 0.17 \mathbf{a b} \mathbf{A B}$ & $0.05 \pm 0.02 \mathbf{a} \quad \mathbf{A C}$ \\
\hline $\begin{array}{l}\text { Base }+ \text { andiroba oil } \\
\text { Base }+ \text { óleo de andiroba }\end{array}$ & $0.06 \pm 0.01 \mathbf{a} \quad \mathbf{A}$ & $0.06 \pm 0.02 \mathbf{a b ~ A B}$ & $0.05 \pm 0.01 \mathbf{a}$ \\
\hline $\begin{array}{l}\text { Base }+ \text { pequi oil } \\
\text { Base }+ \text { óleo de pequi }\end{array}$ & $0.08 \pm 0.04 \mathbf{b c} \quad \mathbf{A}$ & $0.06 \pm 0.01 \mathbf{b}$ & $0.05 \pm 0.01 \mathbf{a}$ \\
\hline $\begin{array}{l}\text { Base }+ \text { buriti oil } \\
\text { Base }+ \text { óleo de buriti }\end{array}$ & $0.07 \pm 0.01 \mathbf{a} \quad \mathbf{A}$ & $0.06 \pm 0.01 \mathbf{b} \quad \mathbf{B}$ & $0.05 \pm 0.01 \mathbf{a}$ \\
\hline
\end{tabular}

Legend: SD - standard deviation $(\mathrm{n}=20)$. Different lowercase letters indicate statistically significant differences between the formulations. Different capital letters indicate statistically significant differences between the cycles.

Legenda: DP - desvio padrão $(\mathrm{n}=20)$. Diferentes letras minúsculas indicam diferenças estatisticamente significativas entre as formulações. Letras maiúsculas diferentes indicam diferenças estatisticamente significativas entre os ciclos.

After the fourth cycle, it was found that the tresses treated with pequi or buriti oils presented an average value of resistance less than the control, however, this average value was statistically equal to those treated with andiroba or babassu oils. The results of the seventh cycle showed that the mean values of tensile strength were statistically equal.

Statistical analysis performed according to the washing cycles, i.e., comparing the first with the fourth cycle and to the seventh, showed different behaviors between the samples. The control showed a statistically signifi-
Depois do quarto ciclo, verificou-se que as mechas tratadas com óleos de pequi ou buriti apresentaram valor médio de resistência menor do que o controle, no entanto, este valor foi estatisticamente igual para aqueles tratados com andiroba ou óleos de babaçu. Os resultados do sétimo ciclo mostraram que os valores médios da resistência à tração foram estatisticamente iguais.

A análise estatística realizada de acordo com os ciclos de lavagem, ou seja, comparando o primeiro com o quarto ciclo e ao sétimo mostraram comportamentos diferentes entre as amostras. O controle apresentou uma 
cant difference between the fourth and seventh wash cycles. There was a decrease in the amount of tensile strength, however, comparing the results of the first with the fourth and seventh there was no statistically significant difference. The same behavior was observed in the group treated with babassu oil. The treatment with andiroba oil showed no statistically significant difference between the first and the seventh cycles and between the fourth and seventh. We observed a reduction in tensile strength with increasing cycles of washes. The application of base, base plus pequi or buriti oil presented statistically significant differences between all cycles. The base formulation showed an increase in the value of tensile strength after four wash cycles and decreased after seven cycles. In contrast, pequi or buriti oils promoted a decrease in tensile strength in the fourth and seventh cycles.

The mechanical properties of hair are attributed to the cortex region of the fiber, which presents greater mass and depends on conditions such as temperature and humidity. The cortex is formed by macrofibrils aligned in the direction of the $\alpha$-keratin wire and is organized into cortical cells, intermacrofibrilar matrix and a cell membrane complex (CMC) (5-7). Vegetable oils are recognized to have preventive action against damage of the outermost layer of the hair fiber coating cortex, called the cuticle. The oils could lubricate the hair shaft, reducing abrasive damage, fill cracks or cavities found in damaged cuticles, and increase protein hydrophobicity, reducing wear on the hair fiber caused by ingress of water into the fiber after repeated washing cycles $(9,10)$.

Tensile strength is a mechanical property attributed to the cortex, and various hair products have appeal as marketing claims such as anti-breakage and increased strength, among others. The tensile strength is obtained by mechanical test patterns that generate tension curves under constant extension rate (9-12).

According to the results of this study, there was no increase in tensile strength compared to the control tress in any of the three cycles. This is likely because oils did not diffuse into the hair fibers and therefore did not reach the cortex, the region responsible for the mechanical properties. The composition of the oils is very important to the its penetration inside the fiber. Oils with a high affinity for hair proteins, low molecular weight and straight chain(s) are able to penetrate into the hair fiber, while the presence of double bonds prevents penetration. According to Rele \& Mohile (13), coconut oil (Cocos nucifera L.) is able to penetrate into the hair fiber $(9,13)$.

The babassu oil is composed predominantly of lauric acid. Buriti oil has $79 \%$ oleic acid, while andiroba oil is basically composed of stearic, palmitic and oleic acid. diferença estatisticamente significativa entre o quarto e sétimo ciclos de lavagem. Houve uma diminuição na resistência à tração, no entanto, comparando os resultados da primeira com a quarta e sétima, não houve diferença estatisticamente significativa. A mesmo comportamento foi observado no grupo tratado com óleo de babaçu. O tratamento com óleo de andiroba, não houve diferença estatisticamente significativa entre o primeiro e o sétimo e entre o quarto e sétimo. A aplicação de base, óleo de pequi ou óleo de buriti apresentaram diferenças estatisticamente significativas entre todos os ciclos. A formulação de base mostrou um aumento do valor de resistência à tração após quatro ciclos de lavagem e diminuiu depois de sete ciclos. Em contraste, os óleos de pequi ou buriti promoveram uma diminuição na resistência à tração após quatro ou sete ciclos.

As propriedades mecânicas das fibras capilares são atribuídos à região do córtex da fibra, que apresenta maior massa, e dependem das condições tais como a temperatura e umidade. O córtex é formado por macrofibrilas alinhadas na direção da $\alpha$-queratina e está organizada em células corticais, matriz intermacrofibrilar e complexo da membrana celular (CMC) (5-7). Os óleos vegetais são reconhecidos por conferir uma ação preventiva contra os danos da camada mais exterior do revestimento de fibra capilar, denominado cutícula. Os óleos podem lubrificar a haste do cabelo reduzindo danos abrasivos, preenchendo fendas ou cavidades encontradas em cutículas danificadas, e aumentar a hidrofobicidade da proteína, reduzindo o desgaste da fibra capilar causado pela entrada de água para dentro da fibra após repetidos ciclos de lavagem $(9,10)$.

A resistência à tração é uma propriedade mecânica atribuída ao córtex e vários produtos capilares apresentam como apelo de marketing os claims: anti-quebra, aumento da força, entre outros (9-12).

De acordo com os resultados, não houve aumento da resistência à tração quando comparado ao controle em qualquer um dos três ciclos porque, provavelmente, os óleos não se difundiram nas fibras do cabelo e, portanto, não atingiram o córtex, região responsável pelas propriedades mecânicas. A composição dos óleos é muito importante para sua penetração no interior da fibra capilar. Óleos com elevada afinidade pelas proteínas do cabelo, de baixo peso molecular e de cadeia linear são capazes de penetrar na fibra capilar, enquanto que a presença de ligações duplas impede a penetração. De acordo com a Rele \& Mohile (13), o óleo de coco (Cocos nucifera L.) é capaz de penetrar na fibra do cabelo $(9,13)$.

O óleo de babaçu é composto, predominantemente, de ácido láurico. O de buriti possui ácido oleico a $79 \%$, enquanto que o óleo de andiroba é basicamente com- 
Pequi oil presents various fatty acids such as palmitic, oleic, myristic, stearic, and linoleic. Oleic acid is unsaturated, that is, it contains double bonds in the molecule which hinder the penetration into the fiber, such that the buriti, andiroba and pequi oils likely did not diffuse into the fiber and, consequently, did not increase the value of tensile strength. The babassu oil, although containing lauric acid, which meets the parameters of penetration, also did not enter the hair fiber according to the values of tensile strength obtained (14).

\section{Conclusion}

In this study, we evaluated the influence of four Brazilian vegetable oils (babassu - Orbignya phalerata Mart, buriti - Mauritia flexuosa L., andiroba - Carapa guianensis Aubl. and pequi - Caryocar brasiliense Camb) on the tensile strength of Caucasian hair submitted to cycles of application of hair care conditioner containing the oils and washing procedures. It was found that there was no statistically significant difference between formulations with oils and the control between the first and seventh cycles. This phenomenon can be explained by lack of penetration of oils in the cortex, a region responsible for the mechanical properties of the hair fiber, since the grease composition disfavors diffusion into the fiber. The common effects of vegetable oils on the cuticle, such as filling of cracks or cavities, lubrication and increased protein hydrophobicity, cannot be excluded, but further studies are required to establish the effects.

\section{Acknowledgment}

We thank Prof. Luiz Antonio Gioielli and Prof ${ }^{a}$. Marice Nogueira de Oliveira for technical support.

\section{Conflict of interests}

The authors declare that there are no financial or personal relations that could be viewed as a potential conflict of interests. posto pelos ácidos esteárico, palmítico e oleico; e o óleo de pequi apresenta vários ácidos graxos, tais como os ácidos palmítico, oleico, mirístico, esteárico e linoleico. O ácido oleico apresenta insaturação na molécula, o que impede a penetração na fibra, de modo que os óleos de buriti, andiroba e pequi provavelmente não se difundiram na fibra e, consequentemente, não se observou aumento na resistência mecânica. $\mathrm{O}$ óleo de babaçu, embora contenha ácido láurico, o qual satisfaz os parâmetros de penetração também não penetra na fibra capilar, de acordo com os resultados obtidos (14).

\section{Conclusão}

Neste estudo, foi avaliada a influência de quatro óleos vegetais brasileiros (babaçu, buriti, andiroba e pequi) na resistência à tração de cabelo Caucasiano submetidos a ciclos compostos por aplicação de condicionador e procedimentos de lavagem. Verificou-se que não havia nenhuma diferença estatisticamente significativa entre as formulações com óleos e o controle entre o primeiro e sétimo ciclos. Este fenómeno pode ser explicado pela falta de penetração de óleos no córtex, região responsável pelas propriedades mecânicas da fibra capilar, uma vez que sua composição desfavorece a difusão para dentro da fibra. Os efeitos comuns de óleos vegetais sobre a cutícula, como preenchimento de fissuras ou cavidades, lubrificação e aumento da hidrofobicidade não pode ser excluídas, mas são necessários mais estudos para estabelecer os efeitos.

\section{Agradecimentos}

Agradecemos Prof. Luiz Antonio Gioielli e Prof ${ }^{a}$. Marice Nogueira de Oliveira para o suporte técnico.

\section{Conflito de interesses}

Os autores declaram que não existem relações financeiras ou pessoais que puderam ser vistas como um potencial conflito de interesses 


\section{References/ Referências}

1. ABIHPEC - Associação Brasileira da Indústria de Higiene Pessoal, Perfumaria e Cosméticos. Panorama do setor de Higiene pessoal, Perfumaria e Cosméticos. Available at http://www.abihpec.org.br; 2014.

2. Simões CMO, Schenkel EP, Gosmann G, Mello JCP, Mentz LA, Petrovick PR. Farmacognosia da planta ao medicamento. Porto Alegre: Editora da Universidade Federal do Rio Grande do Sul; 2004.

3. Pozebon D, Dressler VL, Curtius AJ. Análise de cabelo: Uma revisão dos procedimentos para a determinação de elementos traço e aplicações. Quím Nova 1999; 22:838-46.

4. Robbins CR. Chemical and Physical Behavior of Human Hair. 5.ed. New York: Springer; 2012.

5. Feughelman M. Morphology and properties of hair. In: Johnson DH. Hair and Hair Care. New York: Marcel Dekker; 1997.

6. Nogueira ACS, Dicelio LE, Joekes I. About photo-damage of human hair. Photochem Photobiol Sci 2006; 5:165-69.
7. Nogueira ACS, Joekes I. Hair color changes and protein damage caused by ultraviolet radiation. J Photoch Photobio B 2004; 74:10917.

8. Faria PM, Camargo LN, Carvalho RSH, Paludetti LA, Velasco MVR, Gama RM. Protective effect of argan oil (Argania spinosa Kernel Oil) and cupuassu butter (Theobroma grandiflorum Seed Butter) post treatment with hair dye. Journal of Cosmetics, Dermatological Sciences and Applications 2013; $3: 40-4$.

9. Fregonesi A, Scanavez C, Santos L, Oliveira A, Roesler R, Escudeiro C. Brazilian oils and butters: The effect of different fatty acid chain composition on human hair physiochemical properties. J Cosmet Sci 2009; 60:273-80

10. Garcia MG. The effects of lipid penetration and removal from subsurface microcavities and cracks at the human cuticle sheath. J Cosmet Sci 2009; 60:85-95.
11. Haake HM, Marten S, Seipel W, Eisfeld W. Hair breakage. How to measure and counteract. J Cosmet Sci 2009; 60:143-51.

12. Evans TA. Fatigue testing hair- A statistical approach to hair breakage. J Cosmet Sci 2009; 60:599-616.

13. Rele AA, Mohile RB. Effect of mineral oil, sunflower oil, and coconut oil on prevention of hair damage. J Cosmet Sci 2003; 54:17592.

14. Santos NA. Propriedades termo-oxidativas e de fluxo do biodiesel de babaçu. Master Dissertation, Universidade Federal da Paraíba; 2008. 